\title{
Transcriptional changes in Crassostrea gigas oyster spat following a parental exposure to the herbicide diuron
}

\author{
Rondon Sallan Rodolfo ${ }^{1,2}$, Akcha Farida ${ }^{3}$, Alonso P. ${ }^{4}$, Menard Dominique ${ }^{3}$, Rouxel Julien ${ }^{3}$, \\ Montagnani Caroline ${ }^{1,{ }^{*}}$, Mitta Guillaume ${ }^{2}$, Cosseau C. ${ }^{2}$, Grunau C. ${ }^{2}$
}

${ }^{1}$ Ifremer, IHPE UMR 5244, Univ. Perpignan Via Domitia, CNRS, Univ. Montpellier, F- 34095

Montpellier, France

${ }^{2}$ Univ. Perpignan Via Domitia, IHPE UMR 5244, CNRS, IFREMER, Univ. Montpellier, F-66860

Perpignan, France

${ }^{3}$ Ifremer, Department of Biogeochemistry and Ecotoxicology, Laboratory of Ecotoxicology, Rue de l'ile

d'Yeu, BP 21105, 44311 Nantes Cedex 03, France

${ }^{4}$ CNRS, IHPE UMR 5244, Univ. Perpignan Via Domitia, IFREMER, Univ. Montpellier, F-34095

Montpellier, France

* Corresponding author: Caroline Montagnani, Tel.:+ +33 04671447 07; fax: +33 0467144622 ;

email address : cmontagn@ifremer.fr

\begin{abstract}
:
The Pacific oyster Crassostrea gigas is the main oyster species produced in the world, and a key coastal economic resource in France. High mortalities affect Pacific oysters since 2008 in France and Europe. Their origins have been attributed to a combination of biotic and abiotic factors, underlining the importance of environment quality. The impact of water pollution has been pointed out and one of the pollutants, the genotoxic herbicide diuron, occurs at high concentrations all along the French coasts. Previous work has revealed that a parental exposure to diuron had a strong impact on hatching rates and offspring development even if spats were not exposed to diuron themselves. In this study, we explored for the first time the transcriptional changes occurring in oyster spats (non exposed) originating from genitors exposed to an environmentally relevant concentration of diuron during gametogenesis using the RNAseq methodology. We identified a transcriptomic remodeling revealing an effect of the herbicide. Different molecular pathways involved in energy production, translation and cell proliferation are particularly disturbed. This analysis revealed modulated candidate genes putatively involved in response to oxidative stress and mitochondrial damage in offspring of genitors exposed to diuron. Complementary measures of the activity of enzymes involved in these latter processes corroborate the results obtained at the transcriptomic level. In addition, our results suggested an increase in energy production and mitotic activity in 5-month-spats from diuron-exposed genitors. These results could correspond to a "catch-up growth" phenomenon allowing the spats from diuron-exposed genitors, which displayed a growth delay at 3 months, to gain a normal size when they reach the age of 6 months. These results indicate that exposure to a concentration of diuron that is frequently encountered in the field during the oyster's gametogenesis stage can impact the next generation and may result in fitness disturbance.
\end{abstract}




\section{Highlights}

Remodeling of the transcriptome of the offspring of oysters exposed to diuron. 838 gene which expression is modulated (341 overexpressed and 497 underexpressed). Functions related to cytoskeleton organization, translation, ATP synthesis were activated. Functions linked to transcription and protein degradation were altered. Increase of the transcription of genes involved in energy production, protein synthesis and mitosis. catch-up growth phenomenon could allow the spats to compensate for slower growth.

Keywords : Mollusk, Oyster, diuron, transcriptomic, ecotoxicology 


\section{Introduction}

The Pacific oyster Crassostrea gigas is the main oyster species produced in the world and a key coastal economic resource in France. This species is reared in coastal areas (estuaries, lagoons, open sea) under the persistent threat of chemical pollution. In the context of high-mortality outbreaks affecting Pacific oysters since 2008 in France and the rest of Europe, the origins of which have been attributed to a combination of biotic and abiotic factors, the importance of seawater quality has been pointed out (Samain and Mc Combie, 2008). Bivalve mollusks, as filter-feeding organisms, are known to accumulate metals and some organic pollutants and because of some of their features (abundant, sedentary, tolerant to environmental alterations) have often been considered as sentinel organisms well-suited for biomonitoring the marine environment (Regoli et al., 2006, Vazquez-Boucard et al., 2014).

Amongst hazardous substances, diuron (N0-[3,4-dichlorophenyl]-N,N-dimethyl-urea) is a phenylurea systemic herbicide used to eradicate weeds in non-agricultural areas (roadsides, railways, parks, etc.) (Giacomazzi and Cochet, 2004). Although it has been banned from France since 2008, it is still used as an antifouling biocide in paint formulations (Thomas et al., 2001). Since it is poorly degradated naturally (Tixier et al., 2001), it is detected at high concentrations on French coasts (Munaron et al., 2012, Caquet et al., 2013). Underlining the environmental concern represented by diuron, it is considered as a potential Persistent Organic Pollutants (POP), and is currently evaluated under the Stockholm Convention (http://chm.pops.int)(Scheringer et al., 2012). Depending on their bioaccumulation properties and toxicities, POPs have the potential to bioconcentrate and biomagnify along the food chain, to cause chronic exposure and, finally, to exert toxic effects in wildlife and humans. Most commercial preparations containing diuron are therefore classified in the category of harmful chemicals, and are considered as dangerous for aquatic life as well as for mankind, for which the risk of provoking congenital malformations has been reported (Giacomazzi and Cochet, 2004). In addition, diuron is suspected to be a carcinogenic and genotoxic compound for both humans and aquatic organisms such as fish (Huovinen et al., 2015, Canna-Michaelidou and Nicolaou, 1996).

In C. gigas, direct exposure of adult oysters to an environmentally realistic concentration of diuron (from $0.05 \mu \mathrm{g} / \mathrm{L}$ upwards) has a genotoxic effect in somatic, germ and gamete cells (Akcha et al., 2016). Moreover, an aneugenic effect and a negative impact on development have been observed in the next spat generation (Barranger et al., 2014, Bouilly et al., 2007, Barranger et al., 2015). Diuron triggers a direct genotoxic effect on oyster sperm at concentrations from $0.05 \mu \mathrm{g} / \mathrm{L}$ upwards (Akcha et al., 2012, Mai et al., 2013) and has a negative impact on fertilization (Akcha et al., 2012, Mai et al., 2013). Moreover, previous work showed that exposure of oyster genitors to diuron during gametogenesis resulted in embryotoxic and genotoxic effects on oyster embryos (Barranger et al., 2014, Barranger et al., 2015). Diuron exposure caused differences in hatching rate, delayed embryo-larvae development, an augmentation of developmental abnormalities in D-larvae (Barranger et al., 2014). Parental exposure also triggered clastogenic and aneugenic effects on spats (Barranger et al., 2014, Bouilly et al., 2007). Altogether, these previous studies suggest that parental exposure during gametogenesis could affect the next generation of individuals. 
The main goal of the present study was to determine the molecular basis of the induced phenotypic differences in offspring of exposed parents using a global transcriptomics approach. Only a few works have studied the effects of pollutants at a whole transcriptome level on oysters. Most studies have used Suppression Subtractive Hybridization (SSH) and Microarray approaches to evaluate the effect of a direct exposure to diuron and other chemical pollutants on adult oysters (Chapman et al., 2011, Chapman et al., 2009, Tanguy et al., 2005, Anderson et al., 2015, Collin et al., 2010). Until now, no studies have investigated the effect of herbicide exposure on oyster offspring at the transcriptional level. To address that question, genitor oysters were exposed to environmentally relevant concentrations of diuron and the effect on the transciptome of the offspring was evaluated using a RNA-seq approach. RNA-seq was performed on 3 groups of spats originating from control genitors (not exposed) and from genitors exposed to (i) diuron diluted in acetonitrile as solvent, or (ii) acetonitrile alone. We identified differentially expressed genes belonging to different pathways disturbed by this parental exposure to diuron. These results suggested a clear effect of this herbicide on spat transcriptome.

\section{Materials and methods}

2.1. Genitor origin, diuron exposure, fertilization and embryo culture.

The biological material used for the present study was obtained at the experimental hatchery of Ifremer La Tremblade in the framework of the GIMEPEC project funded by the French National Agency for Research (ANR-CESA-01601). Oyster husbandry, diuron exposure and production of the offspring were previously described by Barranger et al. (2014). Briefly, wild oysters from Marennes-Oléron Bay (France) were exposed during gametogenesis (start and mid-course) to two 7-day exposure pulses to diuron at effective concentrations of $0.2-0.3 \mu \mathrm{g} / \mathrm{L}$ diluted in acetonitrile $(0.005 \% \mathrm{v} / \mathrm{v}$ final concentration). These exposure scenarios are environmentally realistic with exposure times that mimic seasonal rain events and diuron concentrations close to those detected in coastal waters (Munaron et al. 2012; Caquet et al. 2013). At time of spawning, male and female gametes from each genitor lot (seawater control SWC, solvent control SC $(0.005 \%)$ and diuron-exposed group D, 70 individuals per group) were gathered and used to produce the next generation. The embryos from each genitor lot were cultivated until D-larvae for $24 \mathrm{~h}$ and then transferred to the mircronursery at the pediveliger stage, when they were ready to settle. They were grown up to spat stage and then sampled 5 month post-fertilization for the transcriptomic analyses.

\subsection{RNA isolation}

Individual whole tissue samples of oyster spats previously frozen in liquid nitrogen were homogenized in RL1 lysis buffer supplied by the NucleoSpin 96 RNA Tissue Core kit (Macherey-Nagel, France). Total RNA was extracted according to the manufacturer'r protocol. RNA samples were treated with DNase to prevent DNA contamination. Total amount and purity of RNA were checked using NanoDrop ND-1000 spectrophotometer (Thermo Scientific, Les Ulis, France) and the integrity of the RNA was analyzed by capillary electrophoresis with the instrument BioAnalyzer Agilent 2100.

2.3. RT-PCR approach 
The relative expression levels of 23 gene transcripts were analyzed by quantitative RTPCR. The primer sequences used in this work were designed by Rosa et al. (2012) (Supplementary file 1, Table a)(Rosa et al., 2012). Primer efficiency was above 1.8. Complementary DNAs (cDNA) were synthesized from 50 ng RNA samples by using the BioLabs ${ }^{\circledR}$ kit protocol which performs a poly-A reverse transcription. Pooled RNA was used, obtained by equimolar mixture of RNA extractions from 20 individuals.

Quantitative PCR was performed in duplicates in a total volume of $7.5 \mu \mathrm{L}$ with $2.5 \mu \mathrm{L}$ of cDNA (2 ng of equivalent RNA), $0.4 \mu \mathrm{L}$ of each primer (final concentration for each primer: $0.4 \mu \mathrm{M}$ ) and $4.2 \mu \mathrm{L}$ of Cyber Green Mix (Roche) on a Roche Light Cycler 480. The cycling program consisted in $10 \mathrm{~min}$ at $90^{\circ} \mathrm{C}$ followed by 40 cycles of $90^{\circ} \mathrm{C}$ for $10 \mathrm{~s}$, $57^{\circ} \mathrm{C}$ for $20 \mathrm{~s}$ and $72^{\circ} \mathrm{C}$ for $25 \mathrm{~s}$. A melting curve of PCR product was performed to ensure the amplification of a single specific product.

\subsection{Library construction and sequencing}

RNASeq library construction was performed by Acobiom (Montpellier, France) and sequencing was performed by the MGX platform (Montpellier, France) using the Illumina HiSeq2000 sequencing instrument. Two libraries per oyster group (SWC, SC and $\mathrm{D}$ ) were constructed as biological duplicates. The same 20 individuals as the one used for RT-qPCR were divided into two lots of 10 individuals, which were used for these subsequent RNA-Seq analysis (2 pools of 10 individuals per condition). Total RNA from 10 spats was pooled in equal quantities to reach $5 \mu \mathrm{g}$ as template for each cDNA library. The Illumina mRNA-Seq single-end protocol for $100 \mathrm{bp}$ was used according to the manufacturer's protocol with the following modifications: poly-A containing mRNA molecules were purified from $5 \mu \mathrm{g}$ total RNA using poly-T oligo-attached magnetic beads. The purified mRNA was fragmented by addition of $5 \times$ fragmentation buffer (Illumina, Hayward, CA) and was heated at $94^{\circ} \mathrm{C}$ in a thermocycler during 5 min. The fragmentation time of $5 \mathrm{~min}$ is the standard time used in the protocol, which yields to fragments of about $250 \mathrm{bp}$. Single strand libraries of 100 nucleotides were constructed as explained below. First strand cDNA was synthesized using random primers to eliminate the generally observed bias towards the 3' end of the transcript. Second strand cDNA synthesis was done by adding GEX second strand buffer (Illumina, Hayward, CA), dNTPs, RNaseH and DNA polymerase I followed by incubation for $2.5 \mathrm{~h}$ at $16^{\circ} \mathrm{C}$. Second strand cDNA was further subjected to end repair, A-tailing, and adapter ligation in accordance with the manufacturer's protocols. Purified cDNA templates were enriched by 15 cycles of PCR for $10 \mathrm{~s}$ at $98^{\circ} \mathrm{C}, 30 \mathrm{~s}$ at $65^{\circ} \mathrm{C}$, and $30 \mathrm{~s}$ at $72^{\circ} \mathrm{C}$ using PE1.0 and PE2.0 primers and with Fastart taq DNA polymerase (Roche). The samples were cleaned using QIAquick PCR purification columns and eluted in $30 \mu \mathrm{l} \mathrm{EB}$ (Elution Buffer) as per manufacturer's instructions (QIAGEN, CA). Purified cDNA libraries were quantified using Bioanalyzer DNA 100 Chip (Agilent Technology 2100 Bioanalyzer). Samples multiplexed by 2 and 3 lanes were used for sequencing. Fastq reads are available under BioProject accession number PRJNA291364 at the NCBI SRA.

\subsection{Transcriptome analysis}

The workflow applied for RNA-Seq analysis is shown in supplementary files 1 ,

figure a. Raw reads were filtered based on quality phred-score. Phred-scores are 
attributed to each nucleotide in the reads. We discarded reads that present more than 5\% of nucleotides with a phred score below 26 with the Filter by quality tool.

The reference genome, CgigasV9, was modified for the subsequent mapping step by discarding contigs $\leq 5 \mathrm{~Kb}$. TopHat 2 (Kim et al., 2013) was used to map the filtered reads to the modified genome with the following parameters: minimum intron length $=70 \mathrm{bp}$, maximum intron length $=25,000 \mathrm{bp}$, mismatch allowed $=2$. Unmapped reads were discarded using SAMtools. To generate libraries of identical effective size 82,500,000 mapped reads were randomly chosen and sorted according to their position on their scaffolds. PCR duplicates were removed with Remove duplicates V.1.0.0 allowing 4 exact matches followed by a second random picking of 46,000,000 reads for each library. Results of the qRT-PCR were used to choose the best further analysis strategy. Four strategies were tested for the exon-intron reconstruction and the FPKM estimations for one library using Cufflink V.2.1.1 (Trapnell et al., 2012b) and combinations of quartile normalization (with or without) and bias correction (with or without). The exon-intron reconstruction was identical for all strategies; however, the FPKM values were different with and without bias correction. Best correlation between log2 of FPKM values and Cp RT-qPCR raw data of 23 target genes was obtained without bias correction $(r=0.90$; supplementary files 1, figure b) and this strategy was chosen. Exon-intron reconstructions were made for each library and then merged into a single reference file using Cuffmerge V.2.1.1(Trapnell et al., 2012b). This merge file was used subsequently for read counts of each library file using HTSeq V.0.4.1(Anders et al., 2014) with the following parameters: Mode = Union; stranded = no; minimum alignment quality $=10$; feature type $=$ exon. The read counts per gene were used for differential expression analysis with DESeq (Anders and Huber, 2010) and with FPKM per gene with cuffdiff V2.0.1(Trapnell et al., 2012a). Only genes differentially expressed with a false discovery rate (FDR) $<0.01$ in both analyses were retained for further analyses. Tests for differential expression were made for three combinations (SWC vs D, SC vs D and SWC vs SC). Only genes differentially expressed between combinations SWC vs D and SC vs D and not differentially expressed on combination SWC vs SC were considered to be affected by diuron exposure.

\subsection{Functional Gene Ontology annotation}

The transcriptome was reconstructed based on the Cuffmerge annotation and extracted coding sequences were automatically annotated using Blastx searches against the non-redundant nr database of the NCBI (23-jun-2014) using ncbiblast-2.2.26+ and evoking parameters -seg yes -strand both -matrix BLOSUM62 -max_target_seqs 10 -evalue 0.001 and default word size of 3. XML files were loaded onto Blast2GO (Conesa et al., 2005) for GO mapping and annotation with version b2g_sep13 of the B2G database. InterProScan-5-44.0 was used with parameter -f XML to search motifs in local instances of ProDom-2006.1, PIRSF2.84, PfamA-27.0, SMART-6.2, PrositeProfiles-20.89, HAMAP-201302.26, PrositePatterns-20.89, PRINTS-42.0, SuperFamily-1.75, Coils-2.2, and Gene3d- 


\subsection{0 (oct-2013). Interproscan gene ontologies (GO) were merged with Blast2GO GO.}

For GO enrichment analysis, the list of genes considered affected by diuron exposure were compared with the list of all expressed genes to search over-representation of GO terms among diuron affected genes with Blast2GO (Conesa et al., 2005, Bluthgen et al., 2004). Increases in GO terms were considered statistically significant at $\mathrm{p}<0.01$. GO terms with less of 4 genes were eliminated for biological interpretations.

\subsection{Enzyme activity assays}

For each experimental group, six months old spats were individually sampled in each triplicate tank (at least 3 individuals per tank) and stored in liquid nitrogen up to analysis. Cytochrome c oxidase (EC 1.9.3.1) and NADH ubiquinone oxidoreductase (EC 1.6.5.3) activities were measured in the first set of samples by preparing individual mitochrondrial fractions from whole tissue as described in Sussarellu et al. (2013). Samples were thawed in ice in a buffer containing $300 \mathrm{mM}$ sucrose, 30mM HEPES, $100 \mathrm{mM} \mathrm{KCl,} 8 \mathrm{mM}$ EDTA, pH 7.5. The protein concentration of each sample fraction was measured by a colorimetric Bradford method using Bio-Rad protein assay reagent. Cytochrome c oxidase activity was then measured as described by Sussarellu et al. (2013). NADH ubiquinone oxidoreductase activities were measured following the same protocols as those described in Flamment et al. (2012).

The second set of samples was used to prepare whole individual S9 fractions for the measurement of glutathione-S-transferase (GST) (EC 2.5.1.18), catalase (CAT) (EC 1.11.1.6) and superoxide dismutase (SOD) (EC 1.15.1.1) activities. The subcellular fractions were prepared by centrifugation of the Tris-buffered saline $(50 \mathrm{mM}$ Tris- $\mathrm{HCl} \mathrm{pH}$ $7.5,150 \mathrm{mM} \mathrm{NaCl}$ ) homogenates for $15 \mathrm{~min}$ at 9,000 $\mathrm{g}$ at $4 \circ \mathrm{C}$. GST was measured as described by Habig et al. (Habig et al., 1974). CAT and SOD activities were measured as described in Greenwald (1985) and Flohe and Otting (1984), respectively.

Protein concentrations and enzyme activities were both measured using a 96-well microplate spectrofluorimeter reader (Safire, TECAN). Specific activity was expressed in umol min-1 mg-1 protein for CAT and GST, nmol min-1 mg-1 protein for NADH ubiquinone oxidoreductase and $\mathrm{U}$. $\mathrm{mg}^{-1}$ protein for SOD and cytochrome c oxidase. For each enzyme, raw data were analyzed by one-way ANOVA (Statistica Inc. 8.0). Normality and variance homogeneity were checked by Normal p-plot and Hartley test, respectively. When significant $(\mathrm{p}<0.05)$, a Tukey test was realized.

\section{Results and discussion}

Identification of transcript expression affected in spat after parental exposure to diuron Two biological replicates were generated for our three conditions (diuron-exposed, D; solvent-exposed, SC; seawater control, SWC). Each replicate corresponded to a pool of 10 individuals. Transcriptome sequencing of the samples yielded 682,268,711 Illumina single-end reads of $100 \mathrm{bp}$. This corresponded to an average of 113,711,451 million reads by library (see details in Table 1, Figure 1). After quality control, 485,380,657 reads were kept for further analysis with an average of 80,896,776 reads by library. These reads spanned 567,099,296 bp of the reference genome (Cgigas V9) with an average of $94,516,549$ mapped reads by library. The number of mapped reads $(567,099,296$ reads) is 
higher than the number of filter reads used in mapping step (485,380,657 reads, Table 1$)$. This is principally due to multiple mapping of the same reads in duplicated loci in the genome. The exon-intron reconstructions were made independently using mapped reads for each of the six libraries. The six exon-intron reconstructions obtained were merged to get an exhaustive reference transcriptome annotation representative of all the conditions used. We obtained a total of 67,753 transcripts corresponding to 42,462 genes. This transcriptome was de novo annotated using blast2Go. This analysis yielded a Gene Ontology term, an InterProScan number, an Enzyme Code or a sequence description for 31,886 transcripts $(75.09 \%)$. Following these first steps, we removed the duplicate exact reads and 46 million of the remaining reads were randomly picked for each library and used for differential gene expression analysis. These steps allowed us to eliminate the bias due to artificial PCR duplicates and homogenized the read numbers between libraries. Quantification of read abundance and analysis of differential gene expression (DGE) between conditions were performed, using our exon-intron reconstruction as a reference. A good correlation of global transcriptional profile between replicates of the same condition was observed (Supplementary File 1, Figure c). The DGE analysis revealed 1,291; 2,128; and 245 differentially expressed genes for SWC vs D, SC vs D, SC vs SWC comparisons, respectively (pval<0.01 with FDR correction) (Figure 1). Eight hundred and sixty two genes were common in the SWC vs D and SC vs D comparisons. The changes in RNA level were in the same direction between the two comparisons for most of the genes (Supplementary File 1, Figure d). A few exceptions were found: one gene with antagonistic effect, two genes completely repressed in SC condition, 27 genes completely repressed in condition D, and 5 genes only expressed in condition D. Equally, the magnitude of fold-change was very similar between the two comparisons, with afew exception (maximum fold-change difference of 2.92 between the two comparisons). Among those 862 genes, 24 were also differentially expressed in the SWC vs SC comparison (Figure 2) and therefore eliminated from further analysis. The above mentioned gene with an antagonist effect was found between these 24 genes and thus eliminated for the biological interpretations. Consequently, 838 genes were considered to be modulated in spats after diuron exposure of the parents (Supplementary File 2).

Among them, $76.25 \%$ (639 genes) were annotated with a known function. The remaining genes (23.75 \%) corresponded to genes encoding hypothetical proteins (9.31\%, 78 genes) or non-annotated genes (NA; 14.44\%, 121 genes). Among the 838 genes whose expression is modulated, 341 were overexpressed whereas 497 genes were underMexpressed. Interestingly, we found 27 genes whose expression is not detected in the spats from diuron-exposed genitors by comparison with the controls whereas only 5 transcripts are not detected in the two control conditions. This lack of expression in the diuron condition (27 compared to 5 in the control condition) may be linked to the genotoxic effects of diuron, a hypothesis that will be investigated in the future. In order to validate the RNA-seq approach and the HTSeq read counts we use an alternative method of transcript quantification (by RT-qPCR) for 23 randomly picked genes. We checked for a correlation between log2 of HTSeq read counts and Cp RT-qPCR (Supplementary File 1, figures b, e). A strong linear correlation was found between the Cp of RT-QPCR data and $\log 2$ of HTSeq read counts $(r=0.82 ; r=0.84 ; r=0.83$ for SWC, SC and D condition respectively). These results validated our RNA-seq approach and allowed the 
generalization of our interpretation to the set of modulated genes evidenced through this approach (Supplementary File 1, Figure e).

Molecular pathways affected in spats originating from parents exposed to diuron The genes that were identified as being overexpressed (341 genes) or under-expressed (497genes) in the offspring of diuron-exposed genitors were subjected to an exact Fisher test using the blast2Go software ( $p$ value $<0.01$ ) in order to identify pathways enriched at the level of cellular compartments, molecular functions and biological processes (Supplementary files 3 and 4). For the overexpressed genes, 47, 25 and 78 GO terms were enriched in the cellular compartments, molecular functions and biological processes categories, respectively (Supplementary file 3). For under-expressed genes 22, 7 and 70 GO terms were enriched for cellular compartment, molecular function and biological process, respectively (Supplementary file 4). Because many GO terms were statistically relevant and to get a better insight into the pathways modified in response to parental diuron exposure, we classified each GO term into more general sub-categories (Table 2, supplementary files 2,3, 4 and 5). This approach revealed that the overexpressed genes are related to cytoskeleton organization, translation and ATP synthesis in the three levels of the analysis (Cellular Compartment, Molecular Function and Biological Process). Among the most relevant functions underexpressed in response to parental diuron exposure, this analysis revealed pathways involved in transcription and protein degradation. The different molecular pathways identified (Transcription/translation, protein regulation, metabolism and cytoskeleton) are highly relevant and correspond to biological functions that have been previously shown to be modulated in response to different environmental stresses (chemical contamination, hypoxia and infection, as well as extremes of temperature, $\mathrm{pH}$ and turbidity) in oysters (Anderson et al., 2015).

Candidate genes affected by parental diuron exposure

To go further in the identification of key genes affected by diuron exposure, we thoroughly examined one by one all the differentially expressed genes. The aim was to identify candidates that would be relevant to better understand the molecular response of offspring after to the parental exposure to diuron (Table 3).

First, we identified genes involved in glycolysis pathway and energy production. A hexokinase (OYG_10007559) and a glyceraldehyde-3-phosphate dehydrogenase gene (GAPDH; OYG_10010975) were overexpressed in offspring of diuron-exposed parents. This result suggests that spats originating from diuron-exposed genitors might activate energy-consuming processes to cope with residual diuron toxicity and damages. The hexokinase participates to the initial step of glucose metabolism by phosphorylating the glucose to generate the glucose-6-phosphate which is the substrate for different pathways (Wilson, 2003). Indeed, after this phosphorylation step, glucose is sequestered in the cell, and will be used either in the glycolytic pathway or in the pentose phosphate pathway. The overexpression of the other gene involved in glycolysis, GAPDH, could also promote glucose consumption. In addition, another overexpressed gene putatively linked to energy production was identified. It corresponds to a gene involved in beta-oxidation of fatty acids (mitochondrial hydroxyacyl-coenzyme a dehydrogenase; HADH mitochondrial, OYG_10007699). In the same register, several genes involved in oxidative phosphorylation (OXPHOS) were overexpressed; particularly genes encoding 
four subunits of ATP Synthase (see supplementary file 6). More generally, this overexpression of genes involved in glycolysis, beta-oxidation of fatty acids and OXPHOS supports the hypothesis of a necessity to increase transcription of energy production genes in spats from diuron-exposed genitors. Secondly, we identified several overexpressed genes involved in protein synthesis suggesting that protein synthesis could be stimulated. Ribosomal genes and two eukaryotic translation initiation factors were found to be overexpressed (see supplementary file 6). Two other genes involved in ribosome biogenesis and cell proliferation, the pescadillo homolog (PES; OYG_10024464) and the ribosome biogenesis protein nsa2 homolog (NSA2; OYG_10020680) were also overexpressed. Finally, our analysis revealed several overexpressed genes involved in cell cycle. Among these genes, we found the $g 1 \mathrm{~s}$ specific cyclin-d2 (CCND2; OYG_10008051) and the serine threonine-protein kinase wnk1 (WNK1; OYG_10012069).

All these results converge towards an increase of the transcription of genes involved in energy production, protein synthesis and mitosis. This transcriptional increase could correspond to increased needs in energy, protein synthesis and cell proliferation in order to maintain normal levels of these cellular functions and compensate the residual and/or induced cellular damaged by diuron. Previous experiments using the same experimental design revealed that a parental exposure to diuron induced a slower growth rate and a delay in the settlement stage (Barranger, 2014) and more recently, we showed that this delayed growth is completely compensated in 6-month-old spat, i.e. the significant differences in wet weight measured in 3-month-old spats from diuron-exposed genitors (by comparison to the controls) are no longer observed in six-month-old spats (E. Bachere et al. , in prep.). This phenomenon called "catch-up growth" suggests that spat from diuron-exposed parents accelerate their growth rate after settlement. The transcriptomics data obtained in the present work are in agreement with these results. Transcriptional increase of genes involved in energy production, protein synthesis and cell proliferation in 5-month-old spats could reflect this growth acceleration in order to overtake the growth delay. A "catch-up growth" phenomenon has been observed in other bivalve mollusks. In Mytilus edulis, smaller mussels are able to catch up the size of the larger ones during their development (Lauzon-Guay et al., 2005). Similarly, in Mytilus galloprovincialis, Aghzar et al. (2012) observed in a growth dynamic experiment that the smaller sized juveniles showed a higher growth rate than the medium and large size individuals of the same age (Aghzar et al., 2012). In addition, a global transcriptomics analysis in two size classes of pearl oysters (Pinctada fucata) from the same cohort showed that smaller oysters overexpressed genes associated with protein translation, energy production and energy catabolism (Shi and He, 2014). The authors also suggested the existence of a "catch-up growth" for smaller pearl oysters.

Acceleration of metabolic processes could trigger damage of mitochondria and apoptosis, by an excessive production of reactive oxygen species (ROS; Kubli and Gustafsson, 2012). Interestingly, we identified an overexpressed gene that is probably involved in degradation of damaged mitochondria: serine threonine-protein kinase mitochondrial (PINK1; (Kubli and Gustafsson, 2012)(OYG_10025899). Furthermore, we found a gene encoding a specific mitochondrial antioxidant protein, the methionine-r-sulfoxide 
reductase mitochondrial (Cabreiro et al., 2008)(not annotated in C. gigas genome) that is also overexpressed. These overexpressions could indicate a quality-control of mitochondria triggering a mitophagy to avoid the apoptotic state caused by the damaged mitochondria (Kubli and Gustafsson, 2012). Furthermore, we identified two genes involved in calcium entry and exit in the endoplasmic reticulum (ER), which changed expression. The calcium-transporting ATPase sarcoplasmic endoplasmic reticulum (SERCA; partially mapped with OYG_10022016) over-expression could allow an augmentation of the entry of calcium to ER without an exit of calcium by inositol trisphosphate receptor type 1 (IP3R1; mapped with OYG_10013621 and OYG_10013622 together), which is completely repressed, avoiding a calcium overload in the cytoplasm or in mitochondria and allowing cellular survival during stress.

Meta-analyses of data from SSH and microarray studying the effects of chemical stress on oysters (hydrocarbon, metal, and pesticide exposure) showed that $40 \%$ of differentially expressed genes were involved in metabolism (Anderson et al. 2015). Interestingly, an earlier transcriptomic SSH approach evaluating the direct exposure to a herbicide mixture (atrazine, diuron et isoproturon) showed that among the over-expressed genes, the most representative categories are xenobiotics detoxification, cellular cell cycle, cytoskeleton and metabolism (Tanguy et al. 2005). The direct exposure of oysters to herbicide mixtures triggers the differential expression of gene categories common to those identified in the present study in the case of a parental exposure to a single herbicide. The overexpression of energy production, protein synthesis and cell cycle genes could be not solely explained by the "catch-up growth" phenomenon, but also by the chemical stress that oyster parents were exposed to. We observed these consequences of the parental exposure to diuron in the modulation of genes involved in the response to stress like ROS detoxification genes. Indeed, genes encoding Heat Shock Proteins (HSPs) or Universal Stress Proteins (USP) or genes involved in DNA repair were found to be either over- or underexpressed (see supplementary file 6). As an example, among the ROS detoxification genes differentially expressed, we found a catalase (Cat; partially mapped with OYG_10016257) that was underexpressed. Candidate genes involved in DNA repair and detoxification processes are also underexpressed in spats from diuronexposed genitors (Table 3; supplementary file 6). We propose that a negative feedback loop may operate on these genes as the environment in the spat does not require a detoxification and DNA repair anymore. A previous work has demonstrated that the spat stages do not exhibit significant differences in DNA damage and double strand breaks (Barranger et al 2014), although DNA damage induced by diuron were detected on male gametes (Akcha et al 2012). These observations suggested that spats from diuronexposed genitors do not need DNA repair machinery anymore and our results corroborate this hypothesis. Interestingly, a gene encoding transposase was among the most overexpressed ( $>38$ fold change) in spats from diuron-exposed genitors, suggesting that some transposable elements are more active after the parental exposure to diuron. Transposon mobilization in response to stress has been shown in various organisms (Piacentini et al., 2014) and occurs to facilitate evolution and adaptation when the environment is stressful. Transposable elements have been suggested to play an active role in shaping genome variation in C. gigas (Zhang et al., 2012) and shown to be 
mobilized in Lophotrochozoan species exposed to environmental pollutants (CastroFerreira et al., 2014).

Finally, some genes implicated in immunity were also modulated in spats following the parental exposure to diuron. We have evidenced the overexpression of several genes putatively involved in pathogen recognition such as lectins (see supplementary file 6). Another notably overexpressed gene is a map kinase-interacting serine threonine-protein kinase 1 (MNK1; OYG_10011819) which may play a role in gene expression regulation, inflammatory responses, proliferation, survival and in response to environmental stress (Waskiewicz et al., 1997, Moens et al., 2013). In addition, we have found an overexpression of genes encoding various inflammatory cytokines like the lipopolysaccharide-induced TNF-alpha factor (LITAF; (Tang et al., 2006)(OYG_10017759 and OYG_10024159). These LITAFs could be implicated in apoptosis (Hong et al., 2006) and are known to be involved in pathogen response in the oyster C. gigas (Yu et al., 2012). These results suggest that parental exposure might exert modifications of immune response capacities in the next generations. Future investigations should focus on the transgenerational effect of diuron exposure on spat susceptibility to infection in regard to current summer mortality events.

Activity of antioxidants enzymes

In order to investigate further the hypothesis deduced from our transcriptomic approach and establish a link between transcriptional changes and changes in enzyme activity, we decided to study activities of enzymes participating in the antioxidant response. We measured the activity of 3 antioxidant enzymes and two enzyme complexes of the OXPHOS system (Catalase, Glutathione-S-transferase, superoxide dismutase, NADH ubiquinone oxydoreductase and cytochrome c oxidase). We observed significant differences in the CAT activity between the three experimental spat groups $(\mathrm{p}=0.017)$ (Figure 3). As compared to the controls, CAT activity was significantly decreased in spat from diuron-exposed genitors $(\mathrm{p}=0.014)$. This result is highly interesting because it corroborates the result obtained at the transcriptional level as one of the catalase genes present in the $C$. gigas genome is underexpressed $(2.2 \mathrm{x})$ in spat from diuron-exposed genitors. Concerning the effect of the solvent alone on catalase activity, we cannot exclude a slight impact of the solvent exposure alone. A slight decrease after this treatment on catalase activity of spats was also evidenced even if this result was not statistically significant. For the four other enzyme activities we did not find statistically significant differences (GST $(p=0.19)$, SOD $(p=0.32)$, NADH ubiquinone oxidoreductase $(p=0.06)$, and cytochrome c oxidase $(p=0.51))$. Nevertheless, figure 3 shows that in agreement with the RNA-Seq results, GST displayed a decreasing trend in spat from diuron-exposed parents compared to both controls. Cytochrome c oxidase showed also slightly higher activity and 1.7 fold higher RNA-Seq score. The only exception to the rule is NADH oxidoreductase: the gene encoding it is transcriptionally 1.45 fold upregulated but the enzyme activity in offspring from diuron (and solvent) exposed parents is reduced. Details are available in supplementary table (Supplementary file 2). In conclusion, these results suggest that the differences in enzymatic activities could be partly linked to an effect of the diuron of the transcription of the corresponding genes. 


\section{Conclusion}

In this study, we explored for the first time the transcriptional changes occurring in non exposed oyster spats originating from genitors exposed to an environmentally relevant concentration of diuron during gametogenesis using the RNAseq methodology. This global transcriptomic approach revealed a remodeling of the transcriptome. Genes encoding proteins with functions related to cytoskeleton organization, translation and ATP synthesis were activated and functions linked to transcription and protein degradation were altered. To go further in our interpretation, we focused on more specific functions and genes. This analysis revealed modulated candidate genes putatively involved in response to oxidative stress and mitochondrial damage in offspring of genitors exposed to diuron. Complementary measures of the activity of enzymes involved in these last processes corroborate the results obtained at the transcriptomic level. In addition, our results suggest an increase in energy production and mitotic activity in 5month-old spats from diuron-exposed genitors. We propose that this result could explain the growth increase of the spats from diuron exposed genitors (by comparison with control) which display a growth delay at 3 months which is completely overtaken in 6month-old spats ("catch-up growth"). These results indicate that exposure to an ecologically realistic concentration of diuron during oyster gametogenesis stage can impact the next generation. More detailed evidence will be needed in the future to further interpret the regulatory processes involved and understand their implication and impact on offspring physiology and fitness. In addition, induction of altered phenotypes during development in response to environmental pressure might involve epigenetic changes. Future work will investigate the involvement of such mechanisms to evaluate their role in the observed phenotype changes.

\section{Authors' Contributions}

F. Akcha, C. Cosseau, C. Grunau designed research; R. Rondon, P. Alonso, D. Menard, J. Rouxel performed research; F. Akcha, R. Rondon, C. Grunau and C. Cosseau analyzed the data; C. Montagnani, R. Rondon C. Cosseau and G. Mitta wrote the paper.

\section{Acknowledgement}

This work was supported by the French National Agency for Research (GIMEPEC project, ANR CESA-01601), the "Institut Français de Recherche pour l'Exploitation de la Mer" ("French Research Institute for Sea Exploration"'-Ifremer), the "Centre National de la Recherche Scientifique”' (National Centre for Scientific Research-CNRS) and and the University of Perpignan via Domitia. R. Rondon was supported by a PhD grant from Ifremer.

\section{References}

AGHZAR, A., TALBAOUI, M., BENAJIBA, M. \& PRESA, P. (2012) Small-fast growers of Mytilus galloprovincialis do not catch up: an experimental test with sizegraded mussels cultured in longline suspended bags. Mar Freshwater Behav Physiol, 45, 223-234.

AKCHA, F., SPAGNOL, C. \& ROUXEL, J. (2012) Genotoxicity of diuron and glyphosate in oyster spermatozoa and embryos. Aquat Toxicol, 106, 104-113. AKCHA, F., BARRANGER, A., BACHERE, E., BERTHELIN, C.H., PIQUEMAL, D., ALONSO, P., SALLAN, R.R., DIMASTROGIOVANNI, G., PORTE, C., MENARD, D., 
SZCZYBELSKI, A., BENABDELMOUNA, A., AUFFRET, M., ROUXEL, J., BURGEOT, T. (2016) Effects of an environmentally relevant concentration of diuron on oyster genitors during gametogenesis: responses of early molecular and cellular markers and physiological impacts. Environ Sci Pollut Res Int., Jan.16, 1-13.

ANDERS, S. \& HUBER, W. (2010) Differential expression analysis for sequence count data. Genome Biol, 11, R106.

ANDERS, S., PYL, P. T. \& HUBER, W. (2014) HTSeq--a Python framework to work with high-throughput sequencing data. Bioinformatics, 31, 166-9.

ANDERSON, K., TAYLOR, D. A., THOMPSON, E. L., MELWANI, A. R., NAIR, S. V. \& RAFTOS, D. A. (2015) Meta-analysis of studies using suppression subtractive hybridization and microarrays to investigate the effects of environmental stress on gene transcription in oysters. PLoS One, 10, e0118839.

BARRANGER, A., AKCHA, F., ROUXEL, J., BRIZARD, R., MAUROUARD, E., PALLUD, M., MENARD, D., TAPIE, N., BUDZINSKI, H., BURGEOT, T. \& BENABDELMOUNA, A. (2014) Study of genetic damage in the Japanese oyster induced by an environmentally-relevant exposure to diuron: evidence of vertical transmission of DNA damage. Aquat Toxicol, 146, 93-104.

BARRANGER, A., BENABDELMOUNA, A., DEGREMONT, L., BURGEOT, T. \& AKCHA, F. (2015) Parental exposure to environmental concentrations of diuron leads to aneuploidy in embryos of the Pacific oyster, as evidenced by fluorescent in situ hybridization. Aquat Toxicol, 159, 36-43.

BLUTHGEN, N., KIELBASA, S. M., CAJAVEC, B. \& HERZEL, H. (2004) HOMGLcomparing genelists across species and with different accession numbers. Bioinformatics, 20, 125-6.

BOUILLY, K., BONNARD, M., GAGNAIRE, B., RENAULT, T. \& LAPEGUE, S. (2007) Impact of diuron on aneuploidy and hemocyte parameters in Pacific oyster, Crassostrea gigas. Arch Environ Contam Toxicol, 52, 58-63.

CABREIRO, F., PICOT, C. R., PERICHON, M., CASTEL, J., FRIGUET, B. \& PETROPOULOS, I. (2008) Overexpression of mitochondrial methionine sulfoxide reductase B2 protects leukemia cells from oxidative stress-induced cell death and protein damage. J Biol Chem, 283, 16673-81.

CANNA-MICHAELIDOU, S. \& NICOLAOU, A. S. (1996) Evaluation of the genotoxicity potential (by Mutatox test) of ten pesticides found as water pollutants in Cyprus. Sci Total Environ, 193, 27-35.

CAQUET, T., ROUCAUTE, M., MAZZELLA, N., DELMAS, F., MADIGOU, C., FARCY, E., BURGEOT, T., ALLENOU, J. P. \& GABELLEC, R. (2013) Risk assessment of herbicides and booster biocides along estuarine continuums in the Bay of Vilaine area (Brittany, France). Environ Sci Pollut Res Int, 20, 651-66.

CASTRO-FERREIRA, M. P., DE BOER, T. E., COLBOURNE, J. K., VOOIJS, R., VAN GESTEL, C. A., VAN STRAALEN, N. M., SOARES, A. M., AMORIM, M. J. \& ROELOFS, D. (2014) Transcriptome assembly and microarray construction for Enchytraeus crypticus, a model oligochaete to assess stress response mechanisms derived from soil conditions. BMC Genomics, 15, 302.

CHAPMAN, R. W., MANCIA, A., BEAL, M., VELOSO, A., RATHBURN, C., BLAIR, A., HOLLAND, A. F., WARR, G. W., DIDINATO, G., SOKOLOVA, I. M., WIRTH, E. 
F., DUFFY, E. \& SANGER, D. (2011) The transcriptomic responses of the eastern oyster, Crassostrea virginica, to environmental conditions. Mol Ecol, 20, 1431-49. CHAPMAN, R. W., MANCIA, A., BEAL, M., VELOSO, A., RATHBURN, C., BLAIR, A., SANGER, D., HOLLAND, A. F., WARR, G. W. \& DIDONATO, G. (2009) A transcriptomic analysis of land-use impacts on the oyster, Crassostrea virginica, in the South Atlantic bight. Mol Ecol, 18, 2415-25.

COLLIN, H., MEISTERTZHEIM, A. L., DAVID, E., MORAGA, D. \& BOUTET, I. (2010) Response of the Pacific oyster Crassostrea gigas, Thunberg 1793, to pesticide exposure under experimental conditions. J Exp Biol, 213, 4010-7.

CONESA, A., GOTZ, S., GARCIA-GOMEZ, J. M., TEROL, J., TALON, M. \&

ROBLES, M. (2005) Blast2GO: a universal tool for annotation, visualization and analysis in functional genomics research. Bioinformatics, 21, 3674-6.

FLAMMENT, M., RIEUSSET, J., VIDAL, H., SIMARD, G., MALTHIERY, Y., FROMENTY, B. \& DUCLUZEAU, P. H. (2012) Regulation of hepatic mitochondrial metabolism in response to a high fat diet: a longitudinal study in rats. $J$ Physiol Biochem, 68, 335-44.

FLOHE, L. \& OTTING, F. (1984) Superoxide dismutase assays. Methods Enzymol, 105, 93-104.

GIACOMAZZI, S. \& COCHET, N. (2004) Environmental impact of diuron transformation: a review. Chemosphere, 56, 1021-32.

GREENWALD, R. (Ed.) (1985) Handbook of Methods for Oxygen Radicals in Biology and Medicine, New York, Oxford University Press.

HABIG, W. H., PABST, M. J. \& JAKOBY, W. B. (1974) Glutathione S-transferases.

The first enzymatic step in mercapturic acid formation. J Biol Chem, 249, 7130-9.

HONG, Y. H., LILLEHOJ, H. S., LEE, S. H., PARK, D. \& LILLEHOJ, E. P. (2006)

Molecular cloning and characterization of chicken lipopolysaccharide-induced TNFalpha factor (LITAF). Dev Comp Immunol, 30, 919-29.

HUOVINEN, M., LOIKKANEN, J., NAARALA, J. \& VAHAKANGAS, K. (2015)

Toxicity of diuron in human cancer cells. Toxicol In Vitro, 29, 1577-1586.

KIM, D., PERTEA, G., TRAPNELL, C., PIMENTEL, H., KELLEY, R. \& SALZBERG, S. L. (2013) TopHat2: accurate alignment of transcriptomes in the presence of insertions, deletions and gene fusions. Genome Biol, 14, R36.

KUBLI, D. A. \& GUSTAFSSON, A. B. (2012) Mitochondria and mitophagy: the yin and yang of cell death control. Circ Res, 111, 1208-21.

LAUZON-GUAY, J., DIONNE, M., BARBEAU, M. \& HAMILTON, D. (2005) Effects

of seed size and density on growth, tissue-to-shell ratio and survival of cultivated mussels (Mytilus edulis) in Prince Edward Island, Canada. Aquaculture, 250, 652-665.

MAI, H., MORIN, B., PARDON, P., GONZALEZ, P., BUDZINSKI, H. \& CACHOT, J. (2013) Environmental concentrations of irgarol, diuron and S-metolachlor induce deleterious effects on gametes and embryos of the Pacific oyster, Crassostrea gigas. Mar Environ Res, 89, 1-8.

MOENS, U., KOSTENKO, S. \& SVEINBJORNSSON, B. (2013) The Role of MitogenActivated Protein Kinase-Activated Protein Kinases (MAPKAPKs) in Inflammation. Genes (Basel), 4, 101-33.

MUNARON, D., TAPIE, N., BUDZINSKI, H., ANDRAL, B. \& GONZALEZ, J. L. (2012) Pharmaceuticals, alkylphenols and pesticides in Mediterranean coastal waters: 
Results from a pilot survey using passive samplers. Estuarine Coastal and Shelf Science, 114, 82-92.

PIACENTINI, L., FANTI, L., SPECCHIA, V., BOZZETTI, M. P., BERLOCO, M., PALUMBO, G. \& PIMPINELLI, S. (2014) Transposons, environmental changes, and heritable induced phenotypic variability. Chromosoma, 123, 345-54.

REGOLI, F., GORBI, S., FATTORINI, D., TEDESCO, S., NOTTI, A., MACHELLA, N., BOCCHETTI, R., BENEDETTI, M. \& PIVA, F. (2006) Use of the land snail Helix aspersa as sentinel organism for monitoring ecotoxicologic effects of urban pollution: an integrated approach. Environ Health Perspect, 114, 63-9.

ROSA, R. D., DE LORGERIL, J., TAILLIEZ, P., BRUNO, R., PIQUEMAL, D. \& BACHERE, E. (2012) A hemocyte gene expression signature correlated with predictive capacity of oysters to survive Vibrio infections. BMC Genomics, 13, 252.

SAMAIN, J.-F. \& MC COMBIE, H. (2008) Summer mortality of Pacific oyster Crassostrea gigas. The MOREST project, Versailles, QUAE ed.

SCHERINGER, M., STREMPEL, S., HUKARI, S., NG, C. A., BLEPP, M. \& HUNGERBUHLER, K. (2012) How many persistent organic pollutants should we expect? Atmospheric Pollution Research, 3, 383-391.

SHI, Y. \& HE, M. (2014) Differential gene expression identified by RNA-Seq and qPCR in two sizes of pearl oyster (Pinctada fucata). Gene, 538, 313-22.

SUSSARELLU, R., DUDOGNON, T., FABIOUX, C., SOUDANT, P., MORAGA, D. \& KRAFFE, E. (2013) Rapid mitochondrial adjustments in response to short-term hypoxia and re-oxygenation in the Pacific oyster, Crassostrea gigas. J Exp Biol, 216, 1561-9. TANG, X., METZGER, D., LEEMAN, S. \& AMAR, S. (2006) LPS-induced TNF-alpha factor (LITAF)-deficient mice express reduced LPS-induced cytokine: Evidence for LITAF-dependent LPS signaling pathways. Proc Natl Acad Sci U S A, 103, 13777-82. TANGUY, A., BOUTET, I., LAROCHE, J. \& MORAGA, D. (2005) Molecular identification and expression study of differentially regulated genes in the Pacific oyster Crassostrea gigas in response to pesticide exposure. FEBS J, 272, 390-403.

THOMAS, K. V., FILEMAN, T. W., READMAN, J. W. \& WALDOCK, M. J. (2001) Antifouling paint booster biocides in the UK coastal environment and potential risks of biological effects. Mar Pollut Bull, 42, 677-88.

TIXIER, C., SANCELME, M., BONNEMOY, F., CUER, A. \& VESCHAMBRE, H. (2001) Degradation products of a phenylurea herbicide, diuron: Synthesis, ecotoxicity, and biotransformation. Environmental Toxicology and Chemistry, 20, 1381-1389.

TRAPNELL, C., HENDRICKSON, D. G., SAUVAGEAU, M., GOFF, L., RINN, J. L. \& PACHTER, L. (2012a) Differential analysis of gene regulation at transcript resolution with RNA-seq. Nat Biotechnol, 31, 46-53.

TRAPNELL, C., ROBERTS, A., GOFF, L., PERTEA, G., KIM, D., KELLEY, D. R., PIMENTEL, H., SALZBERG, S. L., RINN, J. L. \& PACHTER, L. (2012b) Differential gene and transcript expression analysis of RNA-seq experiments with TopHat and Cufflinks. Nat Protoc, 7, 562-78.

VAZQUEZ-BOUCARD, C., ANGUIANO-VEGA, G., MERCIER, L. \& ROJAS DEL CASTILLO, E. (2014) Pesticide residues, heavy metals, and DNA damage in sentinel oysters Crassostrea gigas from Sinaloa and Sonora, Mexico. J Toxicol Environ Health A, 77, 169-76. 
WASKIEWICZ, A. J., FLYNN, A., PROUD, C. G. \& COOPER, J. A. (1997) Mitogenactivated protein kinases activate the serine/threonine kinases Mnk1 and Mnk2. Embo J, 16, 1909-20.

WILSON, J. E. (2003) Isozymes of mammalian hexokinase: structure, subcellular localization and metabolic function. J Exp Biol, 206, 2049-57.

YU, F., ZHANG, Y. \& YU, Z. (2012) Characteristics and expression patterns of the lipopolysaccharide-induced TNF-alpha factor (LITAF) gene family in the Pacific oyster, Crassostrea gigas. Fish Shellfish Immunol, 33, 899-908.

ZHANG, G., FANG, X., GUO, X., LI, L., LUO, R., XU, F., YANG, P., ZHANG, L., WANG, X., QI, H., XIONG, Z., QUE, H., XIE, Y., HOLLAND, P. W., PAPS, J., ZHU, Y., WU, F., CHEN, Y., WANG, J., PENG, C., MENG, J., YANG, L., LIU, J., WEN, B., ZHANG, N., HUANG, Z., ZHU, Q., FENG, Y., MOUNT, A., HEDGECOCK, D., XU, Z., LIU, Y., DOMAZET-LOSO, T., DU, Y., SUN, X., ZHANG, S., LIU, B., CHENG, P., JIANG, X., LI, J., FAN, D., WANG, W., FU, W., WANG, T., WANG, B., ZHANG, J., PENG, Z., LI, Y., LI, N., CHEN, M., HE, Y., TAN, F., SONG, X., ZHENG, Q., HUANG, R., YANG, H., DU, X., CHEN, L., YANG, M., GAFFNEY, P. M., WANG, S., LUO, L., SHE, Z., MING, Y., HUANG, W., HUANG, B., ZHANG, Y., QU, T., NI, P., MIAO, G., WANG, Q., STEINBERG, C. E., WANG, H., QIAN, L., LIU, X. \& YIN, Y. (2012) The oyster genome reveals stress adaptation and complexity of shell formation. Nature, 490, 49-54. 


\section{FIGURES}

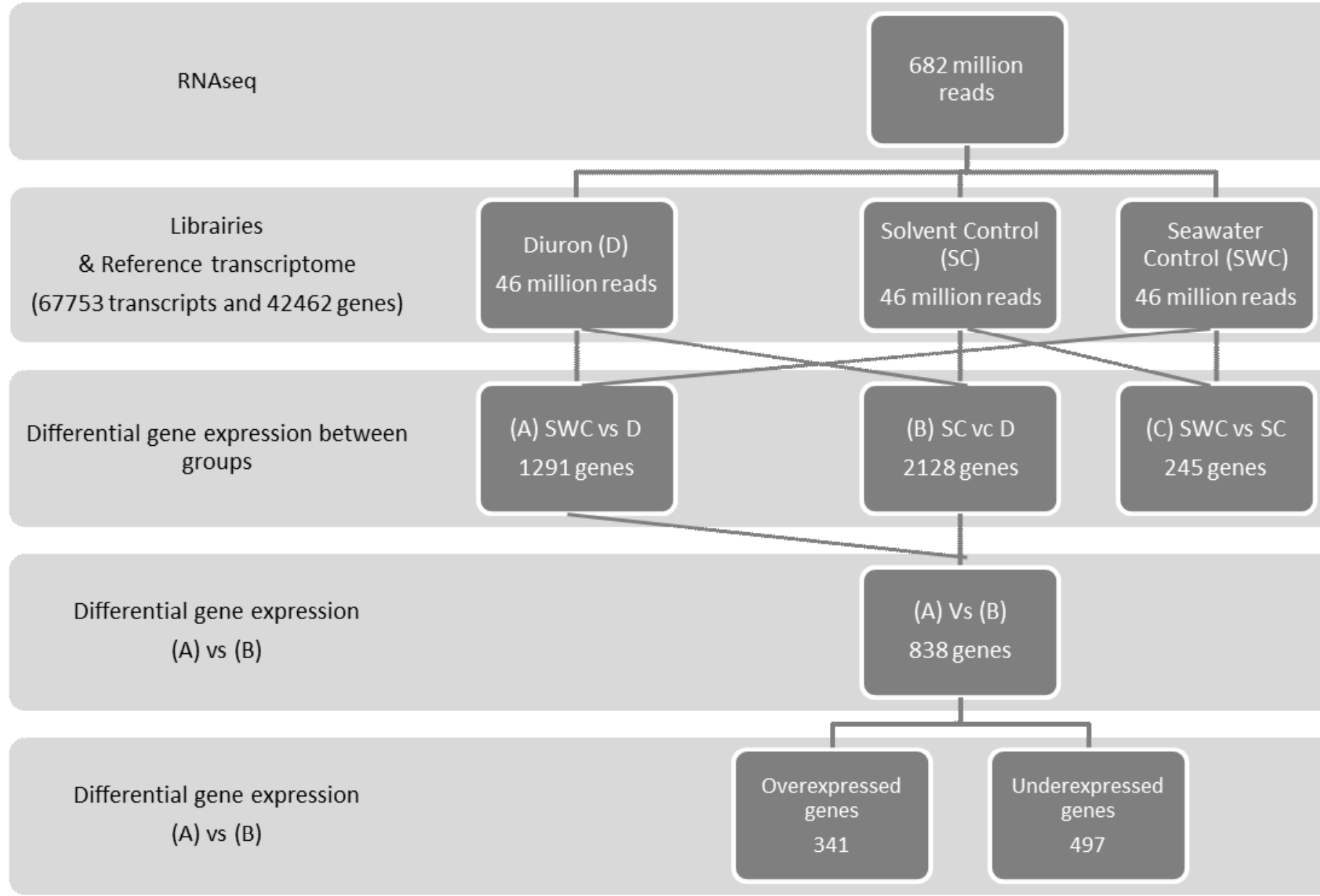

Figure 1. Gene expression profiling process

Each step of the analyses of RNAseq libraries are represented from the raw sequences to library comparison and identification of differentially expressed genes.

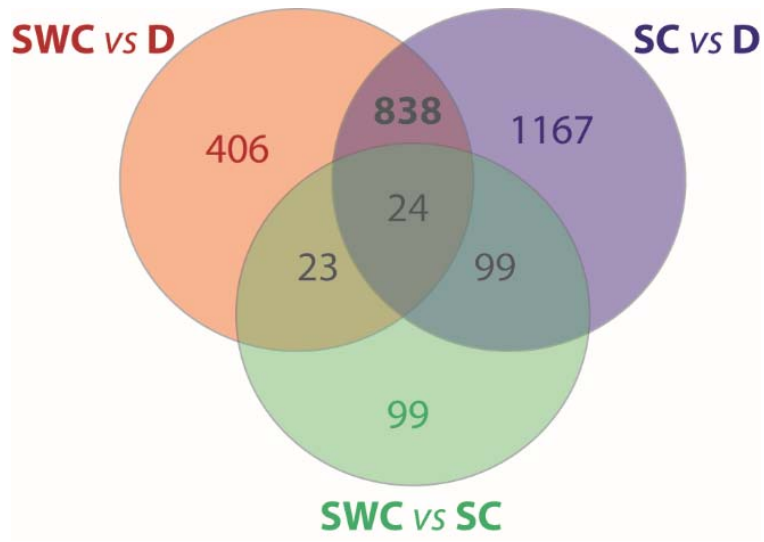

Figure 2. Venn diagram of differentially expressed genes. 
We compared: SWC vs D; SC vs D and SWC vs SC. 862 genes are differentially expressed between A and B among which 24 are differentially expressed in comparison with C. Consequently, 838 genes were considered as affected by a parental exposure to diuron.
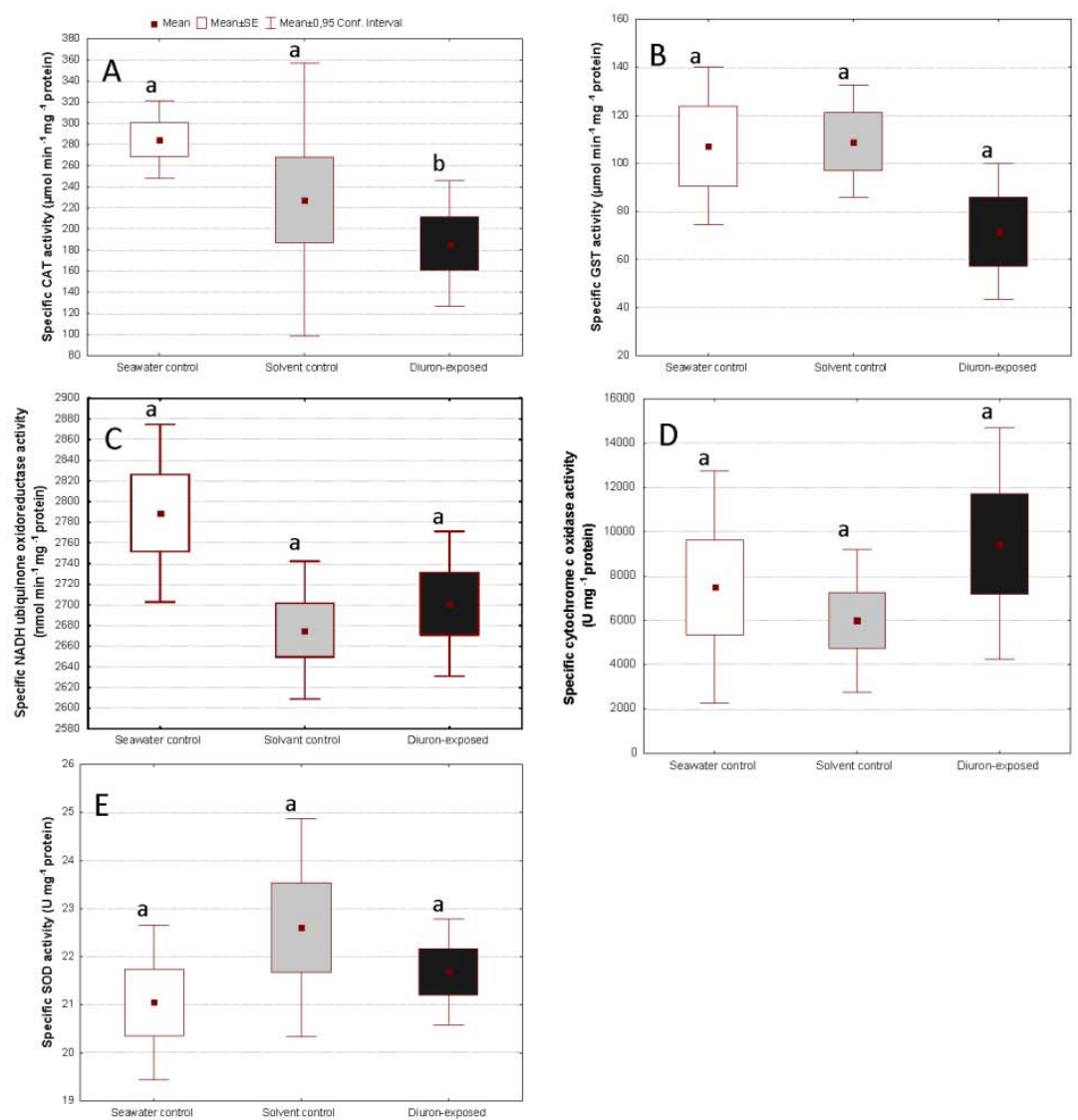

Figure 3. Antioxidant enzyme activities in spats from diuron-exposed genitors. 5 enzyme activities ((A) Catalase-CAT, (B) GST, (C), NADH ubiquinone oxidoreductase, (D) cytC oxidase, (E) SOD) were measured in whole tissue of spats from genitors of the three different groups (SWC, SC, D). Raw data were analyzed by one-way ANOVA (Statistica Inc. 8.0). Normality and variance homogeneity were checked by Normal p-plot and Hartley test, respectively. When significant $(\mathrm{p}<0.05)$ effect with ANOVA was seen, the data were tested with Tukey test.

Significant and non-significant results are indicated by a and b, respectively, in the figure. 
Table 1 Number of reads used at each step for each library.

Final line represents the reads used for the tests of differential gene expression.

\begin{tabular}{|l|l|l|l|l|l|l|l|l|}
\hline \multicolumn{1}{|c|}{ Step } & Diuron 1 & Diuron 2 & $\begin{array}{l}\text { Sea water } \\
\text { Control 1 }\end{array}$ & $\begin{array}{l}\text { Sea water } \\
\text { Control 2 }\end{array}$ & $\begin{array}{l}\text { Solvent } \\
\text { Control 1 }\end{array}$ & $\begin{array}{l}\text { Solvent } \\
\text { Control 2 }\end{array}$ & Total & Average \\
\hline Sequencing & $100,159,793$ & $112,158,055$ & $116,740,743$ & $108,045,894$ & $137,566,967$ & $107,597,259$ & $682,268,711$ & $113,711,452$ \\
\hline Filter by quality & $78,780,619$ & $78,750,534$ & $92,199,309$ & $69,042,405$ & $97,359,760$ & $69,248,030$ & $485,380,657$ & $80,896,776$ \\
\hline Mapping & $88,378,237$ & $88,438,905$ & $111,918,750$ & $82,597,970$ & $111,090,099$ & $84,675,335$ & $567,099,296$ & $94,516,549$ \\
\hline Pick random 1 & $82,500,000$ & $82,500,000$ & $82,500,000$ & $82,500,000$ & $82,500,000$ & $82,500,000$ & $495,000,000$ & $82,500,000$ \\
\hline Duplicate Removal & & & $51,580,004$ & $50,732,863$ & $62,113,788$ & $47,630,423$ & $212,057,078$ & $53,014,270$ \\
\hline Pick random 2 & $46,000,000$ & $46,000,000$ & $46,000,000$ & $46,000,000$ & $46,000,000$ & $46,000,000$ & $276,000,000$ & $46,000,000$ \\
\hline
\end{tabular}

Table 2 Subcategories of GO terms enriched (Fisher exact test) for over- and underexpressed genes following a parental exposure to diuron.

\begin{tabular}{|l|l|l|l|}
\hline Gene group & $\begin{array}{l}\text { Cellular } \\
\text { Compartment }\end{array}$ & Molecular Function & Biological Process \\
\hline Over-expressed & $\begin{array}{l}\text { Intracellular, } \\
\text { Ribosome, } \\
\text { Membrane, } \\
\text { Extracellular Matrix, } \\
\text { Mitochondrion and } \\
\text { Cytoskeleton }\end{array}$ & $\begin{array}{l}\text { Translation, } \\
\text { Cytoskeleton, Ion } \\
\text { transport - ATP Synthase } \\
\text { and Peptidase Inhibitor }\end{array}$ & $\begin{array}{l}\text { Translation, Biosynthetic } \\
\text { Process, Transport - ATP } \\
\text { Synthesis, Cytoskeleton, } \\
\text { Mitosis - Cellular } \\
\text { Components }\end{array}$ \\
\hline Under-expressed & $\begin{array}{l}\text { Intracellular, } \\
\text { Nucleus, Complexes } \\
\text { RNA Polymerase } \\
\text { and Membrane }\end{array}$ & Ion Binding & $\begin{array}{l}\text { Transcription, Metabolic } \\
\text { Process, Catabolic } \\
\text { Process, Biosynthesis } \\
\text { Process, Positive } \\
\text { regulation of cellular and } \\
\text { biological process }\end{array}$ \\
\hline
\end{tabular}

Table 3 Molecular pathways enriched for key genes among over- and under-expressed genes following a parental exposure to diuron.

\begin{tabular}{|l|l|}
\hline Gene group & Molecular pathways* \\
\hline Over-expressed & $\begin{array}{l}\text { Glycolysis, beta oxidation of fatty acids, } \\
\text { OXPHOS, translation, cytoskeleton } \\
\text { organization, mitotic cell cycle, stress response } \\
\text { proteins, mitophagy, Calcium homeostasis and } \\
\text { immunity }\end{array}$ \\
\hline Under-expressed & $\begin{array}{l}\text { Transcription, DNA repair, detoxification, } \\
\text { stress response proteins and Calcium } \\
\text { homeostasis }\end{array}$ \\
\hline
\end{tabular}

* See Supplementary File 6 for details on the genes involved in each molecular pathway. 